\title{
Pengukuran Risiko Gangguan Tidur pada Penggunaan Angiotensin Converting Enzyme Inhibitor dan Calcium Channel Blocker: Case Control Study di Puskesmas Dau, Malang
}

\author{
Martanty Aditya ${ }^{1}$, Rehmadanta Sitepu ${ }^{1}$, Dion Notario ${ }^{2}$, Fibe Y. Cesa ${ }^{1}$ \\ ${ }^{1}$ Program Studi Farmasi, Fakultas Sains dan Teknologi Universitas Ma Chung, Malang, \\ Indonesia, ${ }^{2}$ Program Studi Farmasi, Fakultas Kedokteran dan Ilmu Kesehatan \\ Masyarakat, Universitas Atmajaya, Jakarta, Indonesia
}

\begin{abstract}
Abstrak
Gangguan tidur atau insomnia yang muncul pada pasien hipertensi dapat disebabkan oleh efek samping obat-obat antara lain golongan Angiotensin Converting Enzyme Inhibitor (ACEI) dan Calcium Channel Blocker (CCB), namun besarnya pengaruh masing-masing golongan belum banyak diperbandingkan. Oleh karena itu, dilakukan penelitian dengan menggunakan rancangan case control untuk menilai risiko penggunaan ACEI dan CCB terhadap angka kejadian insomnia. Data demografi dan status insomnia dikumpulkan melalui Lembar Pengumpul Data (LPD) dan kuesioner Athens Insomnia Scale (AIS), kemudian dilakukan analisis univariat, bivariat, dan multivariat. Hasil analisis menunjukkan bahwa pada kelompok usia 56-60 tahun, pasien yang menjalani pengobatan dengan ACEI memiliki risiko insomnia lebih kecil yaitu sekitar 0,38 kali $(p=0,026,95 \% \mathrm{CI}=0,15-0,94)$ dibandingkan dengan pasien lain yang menggunakan $\mathrm{CCB}$, sedangkan pada kelompok kategorial yang lain tidak ditemukan hubungan yang signifikan. Dengan demikian, pemantauan efek samping insomnia menjadi penting untuk dilakukan oleh tenaga kesehatan terutama pada pasien yang menjalani pengobatan dengan CCB pada usia 5660 tahun.
\end{abstract}

Kata kunci: ACE inhibitor, calcium channel blocker, case control, gangguan tidur

\section{A Measurement of Sleep Disorder in the Use of Angiotensin Converting Enzyme Inhibitor and Calcium Channel Blocker: A Case Control Study at Dau Public Health Center, Malang}

\begin{abstract}
Sleep disorder or insomnia arisen in hypertensive patients might be derived as a side effect of antihypertensive mediations such as Angiotensin Converting Enzyme Inhibitor (ACEI) and Calcium Channel Blocker (CCB), but the influence of each group had not been much compared. Therefore, a research was conducted using case control design to assess the risk of using ACEI and CCB against the incidence rate of insomnia. Demographic data and insomnia status were collected through Data Collector Sheet and Athens Insomnia Scale (AIS) questionnaire before univariate, bivariate, and multivariate analysis was conducted. The result showed that in the age group of 56-60 years patients undergoing treatment with ACEI have a smaller risk of insomnia of approximately 0.38 times $(\mathrm{p}=0.026,95 \% \mathrm{CI}=0.15-0.94)$ compared to the other patients who were treated with $\mathrm{CCB}$, while in other categorial groups, no significant relationship was found. Thus, the monitoring of insomnia side effects becomes important to be conducted by healthcare professional especially in patients undergoing treatment with $\mathrm{CCB}$ at the ages of 56-60 years.
\end{abstract}

Keywords: ACE inhibitor, calcium channel blocker, case control, sleep disorder 


\section{Pendahuluan}

Hipertensi adalah suatu sindrom peningkatan tekanan darah secara terus menerus yang dapat menyebabkan komplikasi hingga kematian. ${ }^{1,2}$ Menurut Riset Kesehatan Dasar (Riskesdas) tahun 2013, hipertensi menduduki peringkat ke-6 tertinggi penyakit tidak menular dengan prevalensi sebesar 26,5\% di Indonesia. Provinsi Jawa Timur berada pada urutan ke-12 teratas dengan prevalensi sebesar 26,2\%. ${ }^{1}$

Berdasarkan panduan penatalaksanaan hipertensi yang dikeluarkan oleh American Society of Hypertension, obat-obat golongan Angiotensin Converting Enzyme Inhibitor (ACEI) direkomendasikan sebagai terapi lini pertama yang efektif mengurangi morbiditas dan mortalitas penderita hipertensi dengan komorbid penyakit gagal ginjal kronis, diabetes melitus, riwayat strok, dan gagal jantung. Di lain pihak, Calcium Channel Blocker (CCB) digunakan sebagai terapi lini kedua dalam bentuk kombinasi bersama dengan ACEI kecuali pada pasien gagal jantung. ${ }^{3}$ Meskipun sudah diakui sebagai terapi hipertensi yang resmi, perlu diwaspadai bahwa penggunaan ACEI maupun CCB berisiko menimbulkan efek samping yang tidak diinginkan, terutama gangguan tidur atau insomnia.

Saat ini terdapat beberapa laporan kasus penggunaan antihipertensi yang dihubungkan dengan keluhan gangguan tidur baik itu dalam memulai, mempertahankan, dan/atau awal bangun tidur. ${ }^{4,5}$ Dalam sebuah laporan kasus dengan empat orang pasien, ditemukan bahwa enalapril menyebabkan gangguan tidur yang ditunjukkan oleh penurunan Apnea-Hipopnea Index (AHI) secara signifikan setelah pemberian enalapril dihentikan. ${ }^{6}$ Namun dalam penelitian lain yang dilakukan terhadap pasien diabetes tipe I, tidak ditemukan adanya hubungan yang signifikan antara penggunaan ACEI dengan gangguan tidur. ${ }^{7}$ Dengan demikian, korelasi antara penggunaan ACEI dengan penurunan dari kualitas tidur masih dapat diperdebatkan.
Selain ACEI, dilaporkan bahwa penggunaan obat-obatan lini kedua yaitu golongan CCB memiliki korelasi dengan gangguan tidur yang diukur melalui penurunan rapid eye movement (REM). ${ }^{4}$

Belum banyak literatur-literatur ilmiah yang mengkaji hubungan antara penggunaan $\mathrm{CCB}$ dan risiko terjadinya gangguan tidur, terlebih membandingkan penggunaan CCB dan ACEI. Dalam penelitian ini, disajikan fakta-fakta baru mengenai hubungan kedua faktor risiko yaitu penggunaan ACEI dan CCB dengan angka kejadian efek samping obat yaitu insomnia pada pasien hipertensi. Beberapa temuan pada penelitian yang disajikan di dalam tulisan ini sangat penting bagi praktisi dan akademisi di bidang farmasi klinis terutama sebagai dasar ilmiah dalam memberikan informasi dan melakukan monitoring efek samping obat.

\section{Metode}

Jenis penelitian ini adalah deskriptif analitik, dengan rancangan case control study yang sesuai untuk kasus-kasus yang jarang terjadi. Penelitian ini dilakukan dari bulan Juli sampai Oktober 2018 di Puskesmas Dau Kabupaten Malang. Persetujuan oleh Dinas Kesehatan Kabupaten Malang telah diperoleh sebelum penelitian dijalankan dengan nomor surat 072/ 312/35.07.103.139/2018.

Populasi yang digunakan dalam penelitian ini adalah pasien yang terdaftar dalam kegiatan Pelayanan Terpadu (Posyandu) Puskesmas Dau Kabupaten Malang yang tersebar pada empat wilayah dengan jumlah sebesar 228 responden. Seluruh populasi dijadikan sebagai sampel melalui teknik convenience sampling. Kriteria inklusi antara lain: 1) Pasien anggota posyandu mendapatkan informed consent dan bersedia ikut dalam penelitian; 2) Pasien yang terdiagnosis hipertensi usia 40-60 tahun; dan 3) Mengonsumsi antihipertensi \pm 1 tahun. Kriteria eksklusi dalam penelitian ini adalah: 1) Pasien yang menggunakan antihipertensi 
kombinasi; 2) Pasien dengan kebiasaan tidur yang tidak terkontrol atau seringkali terjaga, dinilai dari durasi waktu tidur kurang dari empat jam yang bukan akibat penggunaan senyawa obat; dan 3) Bekerja dengan system shift. Responden yang memenuhi kriteria inklusi sebanyak 207 orang yang tersebar di wilayah Puskesmas Dau sendiri sebagai pusat sebanyak 67 orang dan tiga lokasi lainnya yaitu Sumbersekar 41 orang, Petungsewu 42 orang dan Tegalweru 57 orang.

Data berupa karakteristik responden yang meliputi jenis kelamin, usia, indeks massa tubuh (IMT), status dan jenis pekerjaan, tekanan darah, kebiasaan/pola tidur pasien, konsumsi teh dan kopi, jenis antihipertensi yang dikonsumsi, serta riwayat merokok dikumpulkan melalui Lembar Pengumpul Data (LPD), sedangkan penilaian insomnia pada masing-masing pasien diukur melalui proses wawancara terstruktur menggunakan kuesioner Athens Insomnia Scale (AIS) yang telah memperoleh izin untuk diterjemahkan dan digunakan di Indonesia. Kuesioner terdiri atas delapan pertanyaan dengan nilai total 24 . Secara khusus, wawancara dilakukan oleh peneliti dan perawat terhadap responden yang buta huruf dan terkendala bahasa (hanya bisa bahasa daerah yaitu Bahasa Jawa). Responden dinyatakan insomnia apabila hasil penilaian menunjukkan angka lebih atau sama dengan enam. ${ }^{8,9}$

Data mentah yang terkumpul dianalisis dengan metode analisis univariat, bivariat dan multivariat. Analisis univariat dilakukan untuk memberikan gambaran tentang karakteristik demografi subjek insomnia (kasus) dan tidak insomnia (nonkasus) serta melihat adanya risiko menggunakan odds ratio (OR) pada karakteristik responden yang terstratifikasi. Analisis bivariat dilakukan menggunakan uji Fisher's exact test untuk mengetahui pengaruh karakteristik pasien yang sudah distratifikasi terhadap kejadian insomnia dalam penggunaan antihipertensi. Identifikasi variabel pengacau yang signifikan dilakukan menggunakan analisis regresi logistik multivariat bertahap menggunakan teknik backward elimination. Perhitungan statistika dilakukan menggunakan perangkat lunak sumber terbuka R. ${ }^{10}$

\section{Hasil}

Sebanyak 207 responden memenuhi kriteria inklusi dan tidak terdapat missing data di dalamnya. Uji validitas dan reliabilitas kuesioner AIS dilakukan dengan melibatkan 30 pasien sebelum disebarluaskan. Kuesioner AIS terbukti reliabel dengan nilai Cronbach Alpha sebesar 0,904 dan valid $(\mathrm{p}<0,05)$ pada semua butir pertanyaan. Sebanyak $40,1 \%$ (83 responden) dikategorikan mengalami insomnia (kasus) dan sebanyak 59,9\% (124 responden) dikategorikan tidak mengalami insomnia (nonkasus). Karakteristik responden penelitian direpresentasikan seperti yang tertera pada Tabel 1.

Representasi karakteristik responden yang ditunjukkan pada Tabel 1 dapat memberikan gambaran kemiripan pada kelompok kasus dan kontrol. Dapat diketahui bahwa responden didominasi oleh jenis kelamin perempuan baik pada kelompok kasus $(28,5 \%)$ maupun nonkasus $(45,89 \%)$ dengan usia responden sebagian besar pada kelompok 56-60 tahun dan pekerjaan terbanyak adalah ibu rumah tangga. Bila dilihat dari nilai IMT, responden didominasi oleh berat badan normal baik pada kelompok kasus $(26,57 \%)$ dan nonkasus (33,33\%). Jumlah penggunaan ACEI adalah $14,98 \%$ untuk kelompok responden kasus dan 27,54\% untuk kelompok responden nonkasus. Pada responden yang menggunakan terapi CCB dihidropiridin, kelompok nonkasus memiliki proporsi sebesar 30,43\% sedangkan kelompok kasus yakni sebesar 23,67\%. Jumlah kelompok kasus dan nonkasus pada pengguna CCB nondihidropiridin berjumlah hampir sama besar dengan proporsi $1,45 \%$ dan 1,93\% secara berturut-turut. Karakteristik responden 
yang memengaruhi terjadinya insomnia dianalisis dengan regresi logistik multivariat dan ditemukan bahwa usia memberi pengaruh terhadap kejadian insomnia $(p=0,028)$ dan berpotensi sebagai variabel pengganggu. Temuan ini selanjutnya dikonfirmasi dengan Fisher's exact test dalam bentuk karakteristik demografi yang distratifikasi yang dapat dilihat pada Tabel 2.

Pada pasien kelompok rentang usia 4145, 46-50, dan 50-55 tahun (jumlah sampel masing-masing 32, 22 dan 28 orang), tidak ditemukan pengaruh yang signifikan antara penggunaan ACEI terhadap risiko insomnia, namun menginjak usia 56-60 tahun terlihat bahwa pengguna ACEI berisiko mengalami insomnia lebih rendah dibandingkan dengan pasien yang menggunakan $\mathrm{CCB}(\mathrm{OR}=0,38$; $\mathrm{p}=0,026 ; \mathrm{n}=101)$. Setelah data pasien yang berusia 56-60 tahun dianalisis dengan regresi logistik multivariat, tidak ditemukan faktor selain penggunaan obat antihipertensi yang berpengaruh secara signifikan terhadap angka kejadian insomnia $(\mathrm{p}=0,027)$. Kesalahan tipe II dapat terjadi pada kelompok usia 41-45, 46-50, dan 50-55 tahun akibat jumlah sampel yang terlalu kecil. Meskipun demikian, setelah dilakukan konfirmasi melalui penggabungan data dari ketiga kelompok strata tersebut dan dilakukan perhitungan ulang, diperoleh simpulan yang sama dengan hasil analisis sebelumnya bahwa tidak terdapat hubungan antara penggunaan ACEI dan risiko insomnia pada pasien hipertensi berusia $40-55$ tahun $(p=0,685 ; n=106)$.

\section{Pembahasan}

Probabilitas kejadian insomnia dipengaruhi oleh beberapa faktor antara lain usia, obesitas yang dipengaruhi oleh ketidakseimbangan hormon atau asupan makanan, perubahan pola waktu tidur akibat pekerjaan, dan peningkatan aktivitas simpatis karena pengaruh konsumsi rokok. Selain itu, tekanan darah atau status hipertensi juga dapat memicu terjadinya gangguan tidur. ${ }^{11}$ Namun, pada penelitian ini tidak semua faktor tersebut berpengaruh signifikan secara statistik. Analisis data dengan regresi logistik menunjukkan bahwa hanya variabel usia yang memiliki pengaruh signifikan terhadap probabilitas terjadinya insomnia pada pasien hipertensi $(\mathrm{p}=0,028)$. Hasil temuan ini berbeda dengan penelitian terdahulu yang menyatakan bahwa pada usia di bawah 60 tahun, seseorang cenderung memiliki risiko insomnia lebih kecil akibat pengaruh faktor hormonal dan perilaku. ${ }^{12,13}$ Setelah ditelaah lebih lanjut dengan analisis terstratifikasi berdasarkan usia, didapatkan bahwa hanya pada usia 56-60 tahun terdapat perbedaan pada probabilitas angka kejadian insomnia yang signifikan di antara pasien yang mengonsumsi ACEI dan CCB (Tabel 2). Pada rentang usia 56-60 tahun, risiko terjadinya insomnia pada pasien hipertensi pengguna ACEI lebih kecil, yakni sekitar 0,38 kali $(p=0,026,95 \% \mathrm{CI}=0,15-0,94)$ dibandingkan penggunaan CCB. Hasil ini didukung oleh penelitian sebelumnya bahwa ACEI tidak memiliki hubungan yang signifikan dengan kejadian insomnia $(\mathrm{p}>0,05))^{7,14}$ Dalam kajian meta-analisis juga dilaporkan tidak terdapat adanya hubungan antara penggunaan ACEI dengan Obstructive Sleep Apnea (OSA). ${ }^{15}$ Risiko gangguan tidur yang lebih tinggi pada penggunaan CCB dihubungkan dengan gangguan tidur khususnya waktu tidur pendek yang disebabkan oleh kejadian OSA. ${ }^{4}$

Dalam beberapa penelitian yang dilakukan terpisah, dilaporkan bahwa CCB berhubungan dengan gangguan tidur pada pasien dengan hipertensi. Menurut Nebrass dkk., penggunaan CCB mempunyai hubungan yang signifikan dengan penurunan durasi dan efisiensi tidur disebabkan hambatan vasokonstriksi hipoksia pulmoner yang diindikasikan oleh durasi $\mathrm{SpO}_{2}$ $<90 \%$ pada pengguna CCB lebih panjang. ${ }^{4}$ Hipoksia berulang dapat menyebabkan aktivasi kemoreseptor untuk meningkatkan aktivitas 
Tabel 1 Karakteristik Responden

\begin{tabular}{|c|c|c|}
\hline Karakteristik & Insomnia $(n=83)$ & Tidak Insomnia $(n=124)$ \\
\hline $\begin{array}{l}\text { Jenis Kelamin } \\
\text { Laki-laki } \\
\text { Perempuan }\end{array}$ & $\begin{array}{l}24(11,59 \%) \\
59(28,50 \%)\end{array}$ & $\begin{array}{l}29(14,01 \%) \\
95(45,89 \%)\end{array}$ \\
\hline $\begin{array}{l}\text { Usia (tahun) } \\
40-45 \\
46-50 \\
51-55 \\
56-60\end{array}$ & $\begin{array}{c}12(5,80 \%) \\
5(2,42 \%) \\
24(11,59 \%) \\
42(20,29 \%)\end{array}$ & $\begin{array}{c}20(9,66 \%) \\
17(8,21 \%) \\
28(13,53 \%) \\
59(28,50 \%)\end{array}$ \\
\hline $\begin{array}{l}\text { Indeks Masa Tubuh (IMT) } \\
\text { Underweight }(<18,5) \\
\text { Normal }(18,5-24,9) \\
\text { Overweight }(25-29,9) \\
\text { Obesitas }(>30)\end{array}$ & $\begin{array}{c}4(1,93 \%) \\
55(26,57 \%) \\
19(9,18 \%) \\
5(2,42 \%)\end{array}$ & $\begin{array}{c}13(6,28 \%) \\
69(33,33 \%) \\
36(17,39 \%) \\
6(2,90 \%)\end{array}$ \\
\hline $\begin{array}{l}\text { Pekerjaan } \\
\text { Tidak Bekerja } \\
\text { Ibu rumah tangga } \\
\text { Pensiunan guru } \\
\text { Pensiunan TNI }\end{array}$ & $\begin{array}{c}56(27,05 \%) \\
1(0,48 \%) \\
1(0,48 \%)\end{array}$ & $\begin{array}{c}94(45,41 \%) \\
0(0,00 \%) \\
0(0,00 \%)\end{array}$ \\
\hline $\begin{array}{l}\text { Bekerja } \\
\text { Petani } \\
\text { Pedagang kue } \\
\text { Pegawai Negeri Sipil (PNS) } \\
\text { Wiraswasta }\end{array}$ & $\begin{array}{c}23(11,11 \%) \\
1(0,48 \%) \\
1(0,48 \%) \\
0(0,00 \%)\end{array}$ & $\begin{array}{c}28(13,53 \%) \\
0(0,00 \%) \\
0(0,00 \%) \\
1(0,48 \%)\end{array}$ \\
\hline $\begin{array}{l}\text { Tekanan Darah } \\
\text { Hipertensi tingkat } 1(140-159 / 90-100) \\
\text { Hipertensi tingkat } 2(160-179 / 90-100) \\
\text { Hipertensi tingkat } 3(\geq 180)\end{array}$ & $\begin{array}{l}21(10,14 \%) \\
25(12,08 \%) \\
37(17,87 \%)\end{array}$ & $\begin{array}{l}38(18,36 \%) \\
30(14,49 \%) \\
56(27,05 \%)\end{array}$ \\
\hline $\begin{array}{l}\text { Kebiasaan Tidur Pasien } \\
\text { 4-6 jam } \\
7-8 \text { jam }\end{array}$ & $\begin{array}{l}60(28,99 \%) \\
23(11,11 \%)\end{array}$ & $\begin{array}{l}67(32,37 \%) \\
57(27,54 \%)\end{array}$ \\
\hline $\begin{array}{l}\text { Konsumsi Teh dan Kopi } \\
1 \text { gelas teh per hari } \\
2 \text { gelas teh per hari } \\
1 \text { gelas kopi per hari } \\
2 \text { gelas kopi per hari } \\
3 \text { gelas kopi per hari } \\
\text { Tidak konsumsi keduanya secara rutin }\end{array}$ & $\begin{array}{c}8(3,86 \%) \\
6(2,90 \%) \\
4(1,93 \%) \\
2(0,97 \%) \\
0(0,00 \%) \\
63(30,43 \%)\end{array}$ & $\begin{array}{c}15(7,25 \%) \\
5(2,42 \%) \\
4(1,93 \%) \\
1(0,48 \%) \\
2(0,97 \%) \\
97(46,86 \%)\end{array}$ \\
\hline $\begin{array}{l}\text { Riwayat Merokok } \\
\text { Merokok } \\
\text { Tidak merokok }\end{array}$ & $\begin{array}{c}0(0,00 \%) \\
83(40,10 \%)\end{array}$ & $\begin{array}{c}2(0,97 \%) \\
122(58,94 \%)\end{array}$ \\
\hline $\begin{array}{l}\text { Obat Antihipertensi yang Digunakan } \\
\text { ACE Inhibitor* } \\
\text { Calcium Channel Blocker (CCB) dihidropiridin** } \\
\text { Calcium Channel Blocker (CCB) nondihidropiridin*** }\end{array}$ & $\begin{array}{c}31(14,98 \%) \\
49(23,67 \%) \\
3(1,45 \%)\end{array}$ & $\begin{array}{c}57(27,54 \%) \\
63(30,43) \\
4(1,93 \%)\end{array}$ \\
\hline
\end{tabular}

Keterangan:

*=CE Inhibitor yang digunakan adalah Kaptopril

$* *=\mathrm{CCB}$ dihidropiridin yang digunakan adalah Amlodipin

$* * *=\mathrm{CCB}$ nondihidropiridin yang digunakan adalah Nifedipin 
Tabel 2 Pengaruh Penggunaan ACEI terhadap Angka Kejadian Insomnia pada Berbagai Faktor

\begin{tabular}{|c|c|c|c|c|c|c|}
\hline Variabel Perancu & $\begin{array}{c}\text { Penggunaan } \\
\text { Antihipertensi }\end{array}$ & Kasus & Kontrol & Total & Nilai $p$ & OR (CI) \\
\hline Perempuan & $\begin{array}{l}\text { ACEI }(+) \\
\text { CCB }(+) \\
\text { Total }\end{array}$ & $\begin{array}{l}24 \\
35 \\
59\end{array}$ & $\begin{array}{l}43 \\
52 \\
95\end{array}$ & $\begin{array}{c}67 \\
87 \\
154\end{array}$ & 0,618 & $0,83(0,41-1,68)$ \\
\hline Laki-laki & $\begin{array}{l}\text { ACEI }(+) \\
\text { CCB }(+) \\
\text { Total }\end{array}$ & $\begin{array}{c}7 \\
17 \\
24\end{array}$ & $\begin{array}{l}14 \\
15 \\
29\end{array}$ & $\begin{array}{l}21 \\
32 \\
53\end{array}$ & 0,174 & $0,45(0,12-1,58)$ \\
\hline IMT kurang & $\begin{array}{l}\text { ACEI }(+) \\
\text { CCB }(+) \\
\text { Total }\end{array}$ & $\begin{array}{l}2 \\
2 \\
4\end{array}$ & $\begin{array}{c}3 \\
10 \\
13\end{array}$ & $\begin{array}{c}5 \\
12 \\
17\end{array}$ & 0,538 & $3,07(0,16-61,74)$ \\
\hline IMT normal & $\begin{array}{l}\text { ACEI }(+) \\
\text { CCB }(+) \\
\text { Total }\end{array}$ & $\begin{array}{l}20 \\
39 \\
59\end{array}$ & $\begin{array}{l}37 \\
38 \\
75\end{array}$ & $\begin{array}{c}57 \\
77 \\
134\end{array}$ & 0,081 & $0,53(0,24-1,12)$ \\
\hline IMT berlebih & $\begin{array}{l}\text { ACEI }(+) \\
\text { CCB }(+) \\
\text { Total }\end{array}$ & $\begin{array}{c}8 \\
7 \\
15\end{array}$ & $\begin{array}{l}13 \\
17 \\
30\end{array}$ & $\begin{array}{l}21 \\
24 \\
45\end{array}$ & 0,546 & $1,48(0,36-6,24)$ \\
\hline IMT obesitas & $\begin{array}{l}\text { ACEI }(+) \\
\text { CCB }(+) \\
\text { Total }\end{array}$ & $\begin{array}{l}1 \\
4 \\
5\end{array}$ & $\begin{array}{l}4 \\
2 \\
6\end{array}$ & $\begin{array}{c}5 \\
6 \\
11\end{array}$ & 0,242 & $0,16(0,00-3,08)$ \\
\hline $40-45$ tahun & $\begin{array}{l}\text { ACEI }(+) \\
\text { CCB }(+) \\
\text { Total }\end{array}$ & $\begin{array}{l}4 \\
5 \\
9\end{array}$ & $\begin{array}{c}8 \\
15 \\
23\end{array}$ & $\begin{array}{l}12 \\
20 \\
32\end{array}$ & 0,696 & $1,48(0,22-9,30)$ \\
\hline 46-50 tahun & $\begin{array}{l}\text { ACEI }(+) \\
\text { CCB }(+) \\
\text { Total }\end{array}$ & $\begin{array}{c}5 \\
8 \\
13\end{array}$ & $\begin{array}{l}1 \\
8 \\
9\end{array}$ & $\begin{array}{c}6 \\
16 \\
22\end{array}$ & 0,333 & $4,67(0,39-265,02)$ \\
\hline $51-55$ tahun & $\begin{array}{l}\text { ACEI }(+) \\
\text { CCB }(+) \\
\text { Total }\end{array}$ & $\begin{array}{c}9 \\
11 \\
20\end{array}$ & $\begin{array}{l}15 \\
17 \\
32\end{array}$ & $\begin{array}{l}24 \\
28 \\
52\end{array}$ & 1,000 & $0,93(0,26-3,27)$ \\
\hline 56-60 tahun & $\begin{array}{l}\text { ACEI }(+) \\
\text { CCB }(+) \\
\text { Total }\end{array}$ & $\begin{array}{l}13 \\
28 \\
41\end{array}$ & $\begin{array}{l}33 \\
27 \\
60\end{array}$ & $\begin{array}{c}46 \\
55 \\
101\end{array}$ & $0,026^{*}$ & $0,38(0,15-0,94)$ \\
\hline Bekerja & $\begin{array}{l}\text { ACEI }(+) \\
\text { CCB }(+) \\
\text { Total }\end{array}$ & $\begin{array}{c}8 \\
17 \\
25\end{array}$ & $\begin{array}{l}14 \\
15 \\
29\end{array}$ & $\begin{array}{l}22 \\
32 \\
54\end{array}$ & 0,274 & $0,51(0,14-1,74)$ \\
\hline Tidak bekerja & $\begin{array}{l}\text { ACEI }(+) \\
\text { CCB }(+) \\
\text { Total }\end{array}$ & $\begin{array}{l}23 \\
35 \\
58\end{array}$ & $\begin{array}{l}43 \\
52 \\
95\end{array}$ & $\begin{array}{c}66 \\
87 \\
153\end{array}$ & 0,507 & $0,80(0,39-1,62)$ \\
\hline Tidak minum kopi & $\begin{array}{l}\text { ACEI }(+) \\
\text { CCB }(+) \\
\text { Total }\end{array}$ & $\begin{array}{l}27 \\
50 \\
77\end{array}$ & $\begin{array}{c}50 \\
67 \\
117\end{array}$ & $\begin{array}{c}77 \\
117 \\
194\end{array}$ & 0,298 & $0,72(0,38-1,36)$ \\
\hline Hipertensi tingkat I & $\begin{array}{l}\text { ACEI }(+) \\
\text { CCB }(+) \\
\text { Total }\end{array}$ & $\begin{array}{l}11 \\
10 \\
21\end{array}$ & $\begin{array}{l}18 \\
20 \\
38\end{array}$ & $\begin{array}{l}29 \\
30 \\
59\end{array}$ & 0,789 & $1,22(0,37-4,07)$ \\
\hline Hipertensi tingkat II & $\begin{array}{l}\text { ACEI }(+) \\
\text { CCB }(+) \\
\text { Total }\end{array}$ & $\begin{array}{c}8 \\
17 \\
25\end{array}$ & $\begin{array}{l}18 \\
12 \\
30\end{array}$ & $\begin{array}{l}26 \\
29 \\
55\end{array}$ & 0,059 & $0,32(0,09-1,08)$ \\
\hline Hipertensi tingkat III & $\begin{array}{l}\text { ACEI }(+) \\
\text { CCB }(+) \\
\text { Total }\end{array}$ & $\begin{array}{l}12 \\
25 \\
37\end{array}$ & $\begin{array}{l}21 \\
35 \\
56\end{array}$ & $\begin{array}{l}33 \\
60 \\
93\end{array}$ & 0,663 & $0,80(0,30-2,08)$ \\
\hline
\end{tabular}


saraf simpatis. ${ }^{16}$ Selain itu, penggunaan CCB (terutama golongan dihidropiridin) juga dapat menyebabkan terjadinya edema tungkai, ${ }^{17}$ peningkatan filtrasi kapiler ke dalam jaringan interstisial (pergeseran cairan) terutama saat posisi berbaring, dan berkontribusi dalam terjadinya hipoksia. ${ }^{4,18}$ Pergeseran cairan ini merupakan salah satu bentuk manifestasi dari Lower Body Positive Preissure (LBPP) sehingga menyebabkan peningkatan airflow resistance of the pharynx (Rph). ${ }^{18}$ Selain itu, akumulasi cairan pada bagian perifaringeal dapat menyebabkan penyempitan faring dan meningkatkan risiko terjadinya OSA. ${ }^{18}$

Dibandingkan dengan $\mathrm{CCB}$, penggunaan ACEI justru menurunkan risiko terjadinya insomnia baik yang ditemukan pada penelitian ini maupun pada penelitian-penelitian yang dilakukan sebelumnya. Penggunaan ACEI secara tidak langsung menghambat aktivitas saraf simpatis melalui inhibisi aldosteron dan lebih jauh penurunan kesadaran saat tidur. ${ }^{19}$ ACEI dengan gugus sulfhidril seperti kaptopril dilaporkan mampu meningkatkan kualitas tidur dan menurunkan desaturasi nokturnal, ${ }^{20}$ sedangkan ACEI dengan gugus dikarboksil seperti enalapril dan lisinopril tidak berakibat pada gangguan tidur meskipun di lain pihak menyebabkan efek samping batuk kering sama halnya dengan fosinopril (ACEI dengan gugus fosfonat). ${ }^{20,21}$ Dalam beberapa penelitian bahkan disebutkan bahwa pemberian kaptoril direkomendasikan bagi gangguan jantung seperti miokard infark ${ }^{22}$ dan gagal jantung ${ }^{19}$ untuk memperbaiki fungsi anatomik dan gangguan tidur.

Terdapat beberapa keterbatasan penelitian ini, yaitu dari sisi metodologi dan jumlah sampel. Pertama, desain penelitian ini, yaitu metode case control, membuat peneliti tidak dapat menarik hubungan kausatif sebab terdapat kemungkinan bahwa pasien lebih dulu mengalami insomnia, lalu hipertensi, dan barulah menggunakan terapi antihipertensi. Kedua, kasus insomnia pada pasien hipertensi termasuk kasus yang jarang ditemui sehingga sampel dalam jumlah yang besar sulit didapat. Meskipun telah dipilih analisis statistik untuk jumlah sampel kecil, namun tidak berarti bahwa dapat dilakukan generalisasi begitu saja pada seluruh populasi. Masih diperlukan studi lebih lanjut dengan jumlah sampel lebih besar dan melibatkan faktor-faktor lainnya yang tidak ikut disertakan dalam penelitian ini namun disinyalir berpengaruh terhadap risiko terjadinya insomnia. Beberapa faktor lain yang mungkin berpengaruh terhadap risiko insomnia dapat berupa obat-obatan antihipertensi lainnya yang digunakan dalam jangka panjang dan/atau pasien yang disertai dengan penyakit penyerta.

\section{Simpulan}

Penggunaan antihipertensi memiliki risiko efek samping berupa insomnia pada kelompok usia 56-60 tahun, namun ACEI memiliki risiko lebih kecil dibandingkan dengan $\mathrm{CCB}$. Hasil penelitian ini menunjukkan urgensi pemantauan efek samping insomnia oleh tenaga kesehatan pada pasien pengguna $\mathrm{CCB}$ berusia 56-60 tahun.

\section{Pendanaan}

Penelitian ini tidak didanai oleh sumber hibah manapun.

\section{Konflik Kepentingan}

Seluruh penulis menyatakan tidak terdapat potensi konflik kepentingan dengan penelitian, kepenulisan (authorship), dan atau publikasi artikel ini.

\section{Daftar Pustaka}

1. Kementerian Kesehatan Republik Indonesia. Riset kesehatan dasar 2013. Jakarta: Kementerian Kesehatan Republik 
Indonesia; 2013.

2. Butt DA, Harvey PJ. Benefits and risks of antihypertensive medications in the elderly. J Intern Med. 2015;278(6):599626. doi: 10.1111/joim.12446.

3. Weber MA, Schiffrin EL, White WB, Mann S, Lindholm LH, Kenerson JG et al. Clinical practice guidelines for the management of hypertension in the community: A statement by the American Society of Hypertension and the International Society of Hypertension. J Clin Hypertens. 2014;16(1):14-26. doi: 10. 1111/jch. 12237.

4. Nerbass FB, Pedrosa RP, Genta PR, Drager LF, Lorenzi-Filho G. Calcium channel blockers are independently associated with short sleep duration in hypertensive patients with obstructive sleep apnea. J Hypertens. 2011;29(6):1236-41. doi: 10. 1097/HJH.0b013e3283462e8b

5. Gupta MA, Knapp K. Cardiovascular and psychiatric morbidity in Obstructive Sleep Apnea (OSA) with Insomnia (sleep apnea plus) versus obstructive sleep apnea without insomnia: A case-control study from a nationally representative US sample. PLoS One. 2014;9(3):e90021. doi: 10.1371/journal.pone.0090021

6. Cicolin A, Mangiardi L, Mutani R, Bucca C. Angiotensin-converting enzyme inhibitors and obstructive sleep apnea. Mayo Clin Proc. 2006;81(1):53-5. doi: 10. 4065/81.1.53

7. van Dijk M, Donga E, van Dijk JG, Lammers GJ, van Kralingen KW, Dekkers OM, M. et al. Disturbed subjective sleep characteristics in adult patients with long-standing type 1 diabetes mellitus. Diabetologia. 2011;54(8):1967-76. doi: 10.1007/s00125-011-2184-7.

8. Soldatos CR, Dikeos DG, Paparrigopoulos TJ. The diagnostic validity of the Athens Insomnia Scale. J Psychosom Res. 2003; 55(3):263-7. doi: 10.1016/s0022-3999(0

\section{2)00604-9}

9. Soldatos CR, Dikeos DG, Paparrigopoulos TJ. Athens Insomnia Scale: Validation of an instrument based on ICD-10 criteria. J Psychosom Res. 2000;48(6):555-60. doi: 10.1016/s0022-3999(00)00095-7

10. $\mathrm{R}$ Core Team. R: A language and environment for statistical computing. Vienna, Austria: R Foundation for Statistical Computing; 2018.

11. Makarem N, Shechter A, Carnethon MR, Mullington JM, Hall MH, Abdalla M, et al. Sleep duration and blood pressure: Recent advances and future directions. Curr Hypertens Rep. 2019;21(5):33. doi: 10.1007/s11906-019-0938-7.

12. Grandner MA, Martin JL, Patel NP, Jackson NJ, Gehrman PR, Pien G. et al. Age and sleep disturbances among American men and women: Data from the U.S. Behavioral Risk Factor Surveillance System. Sleep. 2012;35(3):395-406. doi: 10.5665/sleep. 1704.

13. Jaussent I, Dauvilliers Y, Ancelin ML, Dartigues JF, Tavernier B, Touchon J, et al. Insomnia symptoms in older adults: Associated factors and gender differences. Am J Geriatr Psychiatry. 2011;19(1):8897. doi: 10.1097/JGP.0b0 13e3181e049b6.

14. Van Gastel A. Drug-induced insomnia and excessive sleepiness. Sleep Med Clin. 2018;13(2):147-59. doi: 10.1016/j.jsmc.2 018.02.001.

15. He L Wang B, Lang WY, Xue J, Zhao DL, Li GF, et al. Genetically-reduced serum ACE activity might be a causal risk factor for obstructive sleep apnea syndrome: A meta-analysis. Sci Rep. 2015;5:15267. doi: 10.1038/srep15267

16. Nieto FJ, Young TB, Lind BK, Shahar E, Samet JM, Redline S, et al. Association of sleep-disordered breathing, sleep apnea, and hypertension in a large communitybased study. Sleep heart health study. J Am Med Assoc. 2000;283(14):1829-36. 
doi: 10.1001/jama.283.14.1829

17. Friedman O, Bradley TD, Logan AG. Influence of lower body positive pressure on upper airway cross-sectional area in drugresistant hypertension. Hypertension. 2013;61(1):240-5. doi: 10.1161/HYPERT ENSIONAHA.112.203547

18. Chiu KL, Ryan CM, Shiota S, Ruttanaumpawan P, Arzt M, Haight JS, et al. Fluid shift by lower body positive pressure increases pharyngeal resistance in healthy subjects. Am J Respir Crit Care Med. 2006;174(12):1378-83. doi: 10.116 4/rccm.200607-927OC

19. Jiménez JA, Greenberg BH, Mills PJ. Effects of heart failure and its pharmacological management on sleep. Drug Discov Today Dis Models. 2012;8(4): 161-166. doi: 10. 1016/j.ddmod.2011.02.006
20. Walsh JT, Andrews R, Starling R, Cowley AJ, Johnston ID, Kinnear WJ. Effects of captopril and oxygen on sleep apnoea in patients with mild to moderate congestive cardiac failure. Br Heart J. 1995;73(3): 237-41. doi: 10.1136/hrt.73.3.237

21. Sangole NV, Dadkar VN. Adverse drug reaction monitoring with angiotensin converting enzyme inhibitors: A prospective, randomized, open-label, comparative study. Indian J Pharmacol. 2010;42(1):27-31. doi: 10.4103/0253-7613.624 08 .

22. Lin WL, Chen YR, Lai CT, Yamada S, Liu $\mathrm{SH}$, Chou YH, et al. Neural mechanism of angiotensin-converting enzyme inhibitors in improving heart rate variability and sleep disturbance after myocardial infarction. Sleep Med. 2018;48:61-9. doi: 10.1016/j. sleep.2018.04.007.

(C) 2019 Aditya et al. The full terms of this license incorporate the Creative Common Attribution-Non Commercial License (https://creative commons.org/licenses/by-nc/4.0/). By accessing the work you hereby accept the terms. Non-commercial use of the work are permitted without any further permission, provided the work is properly attributed. 